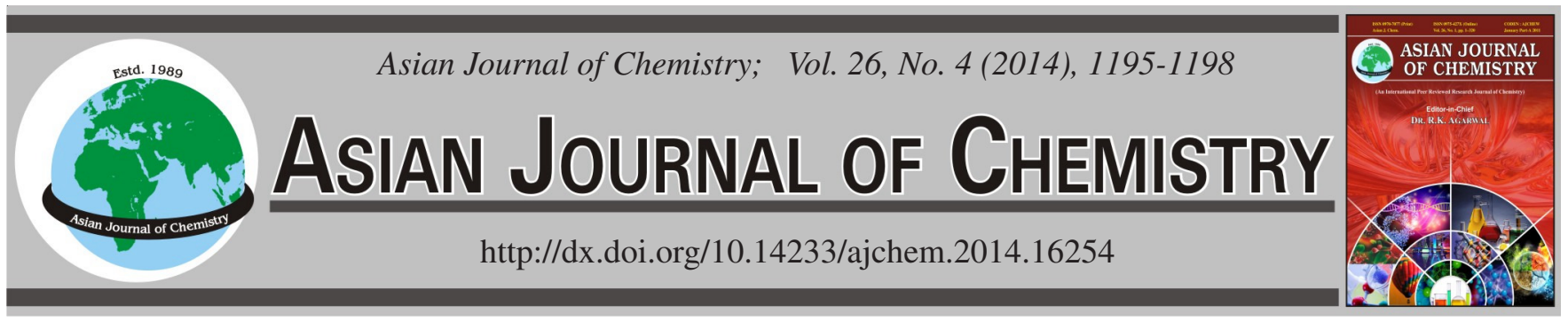

\title{
GC-MS Analysis of Petroleum Ether Extracts in Resource Plant of Mussaenda esquirolli Lévl. Leaves
}

XiaO-Qian Hu*, Yang Yang, Zheng-Dao Su and Xin-Sheng TANG

College of Life and Environment Sciences, Huangshan University, Huangshan 245041, Anhui Province, P.R. China

*Corresponding author: Tel: +86 13515596861, E-mail: hxq@ @su.edu.cn

Received: 29 August 2013; $\quad$ Accepted: 12 December 2013; $\quad$ Published online: 15 February 2014;

AJC-14727

Mussaenda esquirolli Lévl., belonging to the family Rubiaceae, is an important resource plant in China with medicinal, healthy, landscaping
and ornamental value. In the present study, both no decolorization and decolorization petroleum ether extracts in leaves of Mussaenda
esquirolli Lévl., were subjected to GC-MS analysis, respectively. The results showed that the major chemical constituents are phytol
$(37.49 \%, 42.86 \%)$, squalene $(5.59 \%, 47.15 \%)$, linolenic acid $(9.79 \%)$ and $\beta$-sitosterol acetate $(15.49 \%)$, all of which have high use value.
The study provided the medicinal and health function for Mussaenda esquirolli Lévl. on the basis of the chemical compositions.

Keywords: Resource plant, Mussaenda esquirolli Lévl., Gas chromatography-mass spectrometry, Phytol, Squalene.

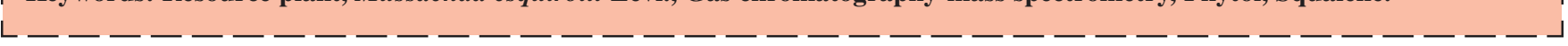

\section{INTRODUCTION}

Mussaenda is a paleotropical genus of 132 species $^{1}$, with 30 species occurring in $\mathrm{China}^{2}$. Species in Mussaenda are characterized by having enlarged petaloid calyx lobes, valvatereduplicate aestivation of the corolla lobes and indehiscent, berry-like fruits and the woody, scandent or liana habit ${ }^{3}$. At present, Mussaenda (Rubiaceae) from China were studied rarely. The research contents of Mussaenda (Rubiaceae) were about made to heathy tea for clearing away heat, species identification $^{3,4}$ and tissue culture ${ }^{5}$. There are less studies on the extraction component analysis and function research of bioactive constituent from Mussaenda (Rubiaceae). Only some bioactive constituents of Mussaenda frondosa Linn were identified with the aid of GC-MS technique ${ }^{6}$.

Mussaenda esquirolli Lévl. (Fig. 1) belongs to Mus-saenda, Rubiaceae, Gentianales in botany classification. Mussaenda esquirolli Lévl. is an important resource plant in China with ornamental, medicinal, healthy, landscaping value, etc. ${ }^{7}$. The current study was carried out to GC-MS analysis of the active phytochemical constituents by petroleum ether in the leaves of Mussaenda esquirolli Lévl. The objective is to provide the medicinal and health function for Mussaenda esquirolli Lévl. on the basis of the chemical compositions.

\section{EXPERIMENTAL}

Mussaenda esquirolli Lévl. was collected in Anhui Qingliang Mountain National Nature Reserve, which was identified and authenticated by Prof. Hui-Chong Zhang, College

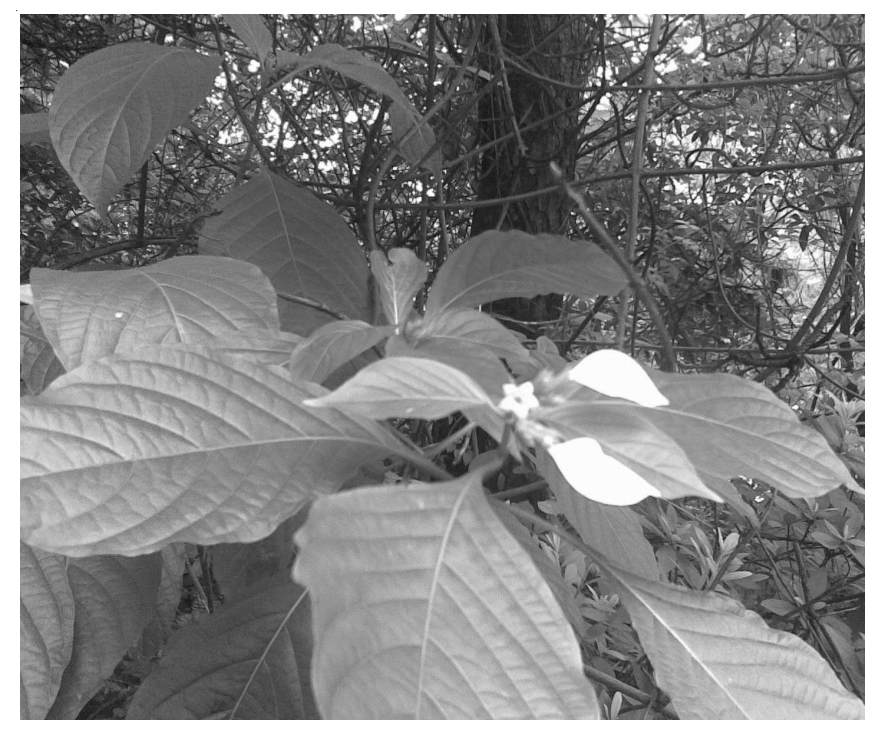

Fig. 1. Photographic images of Mussaenda esquirolli Lévl.

of Life and Environment Sciences, Huangshan University, Huangshan, Anhui, China.

Sample preparation: The fresh leaves of Mussaenda esquirolli Lévl. were obtained in June, 2012. The leaves were washed thoroughly with distilled water, dried in the thermostat at $60{ }^{\circ} \mathrm{C}$ and then pulverized to powder.

Petroleum ether extraction: Mussaenda esquirolli Lévl. leaf powder $(2.5 \mathrm{~g})$ was extracted with petroleum ether (125 $\mathrm{mL}$ ) in Soxhlet extractor at $90^{\circ} \mathrm{C}$ for $2 \mathrm{~h}$ to get no decolorization extraction. This extraction process was repeated once, followed 
by decolorization with activated carbon to get decolorization extraction. The two extract samples were concentrated under reduced pressure in a rotary evaporator at $45^{\circ} \mathrm{C}$ respectively and stored in a refrigerator at $4{ }^{\circ} \mathrm{C}$ until to use.

Gas chromatography-mass spectroscopy: The no decolorization and decolorization petroleum ether extraction were subjected to GC-MS analysis (Agilent 6890N GC and 5973 inert MSD) using a pulsed pressure injection of $1 \mathrm{~mL}$ onto a HP-5 MS capillary column $(30 \mathrm{~m} \times 250 \mu \mathrm{m} \times 0.25 \mu \mathrm{m})$ with electron ionization mode (EI). The initial temperature was programmed from 60 to $290^{\circ} \mathrm{C}$ (at $5^{\circ} \mathrm{C} / \mathrm{min}$ ) and maintained at $290{ }^{\circ} \mathrm{C}$ for $20 \mathrm{~min}$ and then to $325^{\circ} \mathrm{C}$. Helium $(99.999 \%)$ was used as carrier gas at a constant flow of $1 \mathrm{~mL} / \mathrm{min}$. The injection volume was $0.5 \mu \mathrm{L}$ and the split ratio was $10: 1$. The ionization mass spectroscopic analysis was done with $70 \mathrm{eV}$ and the ion-source temperature was $230{ }^{\circ} \mathrm{C}$.

Identification of components: The identification of compounds was based on the comparisons of their mass spectra with National Institute Standard and Technology (NIST) Library 2008 WILEY8, FAME ${ }^{8}$.

\section{RESULTS AND DISCUSSION}

GC-MS analysis of the no decolorization petroleum ether extract: GC-MS chromatogram of the no decolorization petro-leum ether extract of Mussaenda esquirolli Lévl. (Fig. 2) showed many peaks indicating the presence of many phytochemical constituents. Comparison of the mass spectra of the constituents with the NIST library, the thirty-five phytoconstituents were characterized and identified (Table-1), accounting for $85.9 \%$ of the no decolorization petroleum ether extract. The no decolorization petroleum ether extract mainly comprised of alcohols accounted for $39.07 \%$ (phytol accounted for $37.49 \%$ ), ester compounds accounted for $18.15 \%$ ( $\beta$-sitosterol acetate accounted for $15.49 \%)$, carboxylic acid compounds accounted for $10.27 \%$ (linolenic acid accounted for $9.79 \%$ ), olefin(e) compounds accounted for $6.60 \%$ (squalane accounted for $5.59 \%$ ), alkane compounds accounted for $6.23 \%$ and heterocyclic compounds accounted for $4.42 \%$.

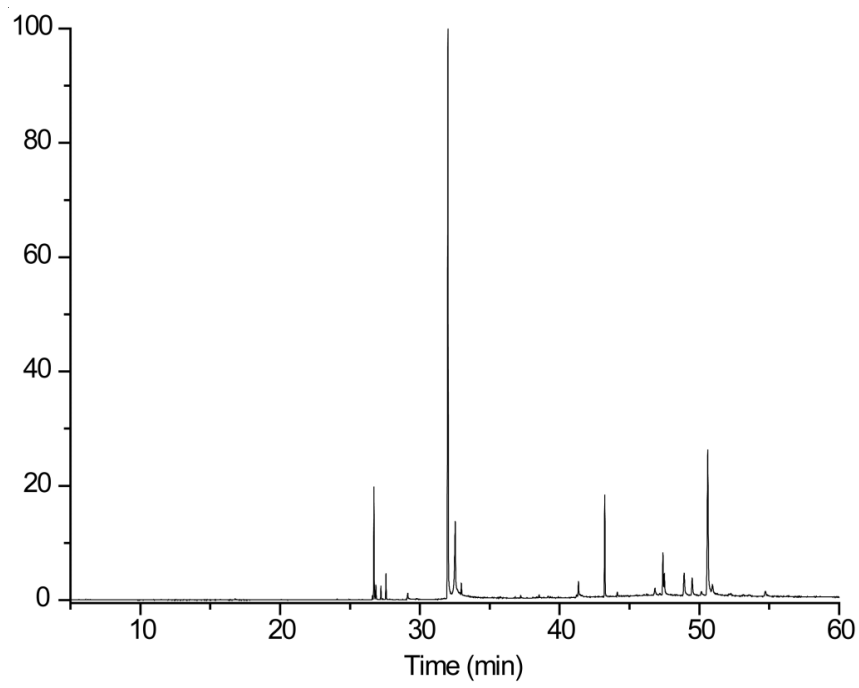

Fig. 2. GC-MS chromatogram of the no decolorization petroleum ether extract of the leaf of Mussaenda esquirolli Lévl
GC-MS analysis of the decolorization petroleum ether extract: GC-MS chromatogram of the decolorization petroleum ether extract of Mussaenda esquirolli Lévl. (Fig. 3) showed 6 peaks. Comparison of the mass spectra of the constituents with the NIST library, the four phytoconstituents were characterized and identified (Table 2), accounting for $97.75 \%$ of the decolorization petroleum ether extract. Compared with Table 1, with the activated carbon decolorization, phytol concentration increased to $42.86 \%$ and squalene content swelled to $47.15 \%$.

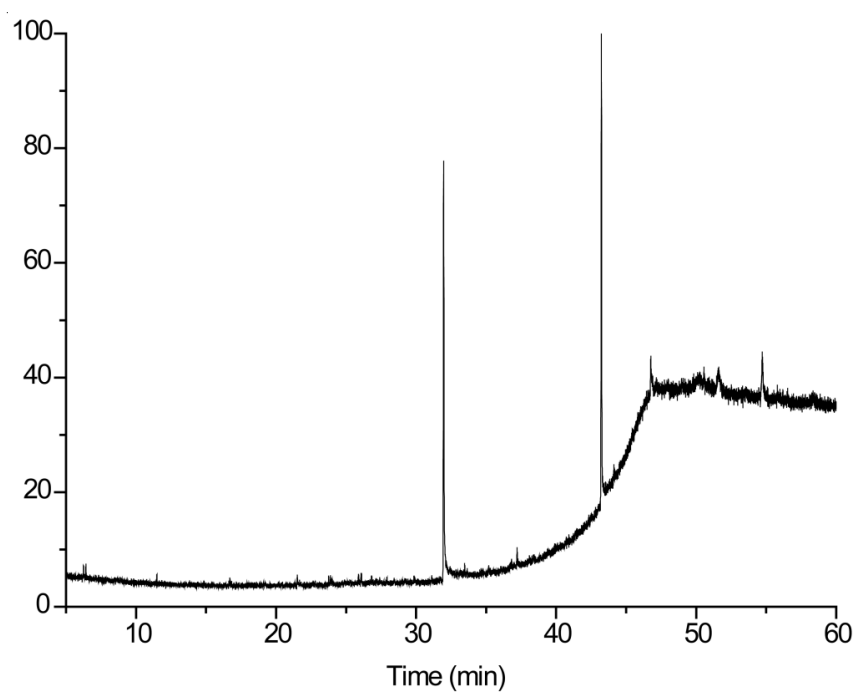

Fig. 3. GC-MS chromatogram of the decolorization petroleum ether extract of the leaves of Mussaenda esquirolli Lévl.

By GC-MS analysis of the no decolorization and decolorization petroleum ether extracts, there were many bioactive substances, such as phytol, squalene, linolenic acid, $\beta$-sitosterol acetate, linolenic acid ethyl ester, palmitic acid, pinane etc.. The presence of such a variety of phytochemicals may be attributed to the medicinal function and health care function of Mussaenda esquirolli Lévl.. Especially, there were four phytocomponents accounted for a higher proportion, which were linolenic acid, phytol, squalene and $\beta$-sitosterol acetate.

Linolenic acid: Linolenic acid is unsaturated essential fatty acid which cannot be synthesized in the human body and is a major component of human tissues and cells. Linolenic acid can promote energy production, lower blood fat and cholesterol, defer senescence, anti-allergic and inhibit the development and metastasis of cancer ${ }^{9}$, so linolenic acid have important significance to the health of human body. Linolenic acid was rich in Mussaenda esquirolli Lévl., which may contribute to some health functions of Mussaenda esquirolli Lévl..

Phytol: Phytol, the side chain of chlorophyll, is called leaf alcohol for short. It belongs to fatty alcohol and is the raw material to synthesize vitamin $\mathrm{K}$ and vitamin $\mathrm{E}$, which could prevent teratogenesis ${ }^{10}$. Phytol is not only an important source of energy in the body metabolism, but also can be used as signal molecules with special biological functions in glucose and lipid metabolism ${ }^{11}$. Phytol can significantly reduce the fatty acids in the blood plasma, increase free carnitine levels 


\begin{tabular}{|c|c|c|c|c|c|}
\hline \multicolumn{6}{|c|}{$\begin{array}{l}\text { PHYTOCOMPONENTS IDENTIFIED IN THE NO DECOLORIZATION PETROLEUM ETHER } \\
\text { EXTRACT OF THE LEAVES OF Mussaenda esquirolli Lévl. }\end{array}$} \\
\hline No. & $\mathrm{RT}(\min )$ & Phytoconstituents & m.w. & m.f. & Peak area $(\%)$ \\
\hline 1 & 2.82 & Methylbenzene & 92 & $\mathrm{C}_{7} \mathrm{H}_{8}$ & 0.11 \\
\hline 2 & 2.90 & 1,3-Two methyl cyclohexane & 112 & $\mathrm{C}_{8} \mathrm{H}_{16}$ & 0.08 \\
\hline 3 & 4.04 & $p$-Xylene & 106 & $\mathrm{C}_{8} \mathrm{H}_{10}$ & 0.08 \\
\hline 4 & 16.79 & 2-Methyl pyrrolidone & 81 & $\mathrm{C}_{5} \mathrm{H}_{7} \mathrm{~N}$ & 0.07 \\
\hline 5 & 26.72 & Pinane & 138 & $\mathrm{C}_{10} \mathrm{H}_{18}$ & 5.32 \\
\hline 6 & 26.85 & 2-Methyl-2-cyclohexyl butane & 154 & $\mathrm{C}_{11} \mathrm{H}_{22}$ & 0.91 \\
\hline 7 & 27.22 & 9-Eighteen carbyne & 250 & $\mathrm{C}_{18} \mathrm{H}_{34}$ & 0.69 \\
\hline 8 & 27.35 & Diisobutyl phthalate & 278 & $\mathrm{C}_{16} \mathrm{H}_{22} \mathrm{O}_{4}$ & 0.07 \\
\hline 9 & 29.14 & Palmitic acid & 256 & $\mathrm{C}_{16} \mathrm{H}_{32} \mathrm{O}_{2}$ & 0.48 \\
\hline 10 & 32.01 & Phytol & 297 & $\mathrm{C}_{20} \mathrm{H}_{40} \mathrm{O}$ & 37.49 \\
\hline 11 & 32.53 & Linolenic acid & 278 & $\mathrm{C}_{18} \mathrm{H}_{30} \mathrm{O}_{2}$ & 9.79 \\
\hline 12 & 32.84 & Ethyl linoleate & 308 & $\mathrm{C}_{20} \mathrm{H}_{36} \mathrm{O}_{2}$ & 0.57 \\
\hline 13 & 35.26 & 2-Methyl-5-(1-methyl vinyl)-2-cyclohexene-1-ketone & 150 & $\mathrm{C}_{10} \mathrm{H}_{14} \mathrm{O}$ & 0.27 \\
\hline 14 & 37.22 & 2,2'-Methylene bis-4-methyl-6- tert-butyl phenol & 340 & $\mathrm{C}_{23} \mathrm{H}_{32} \mathrm{O}_{2}$ & 0.16 \\
\hline 15 & 38.38 & Tetracosane & 339 & $\mathrm{C}_{24} \mathrm{H}_{50}$ & 0.09 \\
\hline 16 & 38.53 & Glyceryl fatty esters & 331 & $\mathrm{C}_{19} \mathrm{H}_{38} \mathrm{O}_{4}$ & 0.27 \\
\hline 17 & 39.18 & Phthalic acid mono-2-ethylhexyl ester & 278 & $\mathrm{C}_{16} \mathrm{H}_{22} \mathrm{O}_{4}$ & 0.18 \\
\hline 18 & 41.22 & Isopropyl linoleate & 322 & $\mathrm{C}_{21} \mathrm{H}_{38} \mathrm{O}_{2}$ & 0.20 \\
\hline 19 & 41.35 & Linolenic acid ethyl ester & 306 & $\mathrm{C}_{20} \mathrm{H}_{34} \mathrm{O}_{2}$ & 1.24 \\
\hline 20 & 41.50 & 3,5-Dichloro-2-pyridone & 164 & $\mathrm{C}_{5} \mathrm{H}_{3} \mathrm{Cl}_{2} \mathrm{NO}$ & 0.13 \\
\hline 21 & 41.61 & Dimethyl hexadecanedioate & 314 & $\mathrm{C}_{18} \mathrm{H}_{34} \mathrm{O}_{4}$ & 0.13 \\
\hline 22 & 43.23 & Squalane & 411 & $\mathrm{C}_{30} \mathrm{H}_{50}$ & 5.59 \\
\hline 23 & 44.13 & 1-Nonadecene & 266 & $\mathrm{C}_{19} \mathrm{H}_{38}$ & 0.35 \\
\hline 24 & 46.03 & Aminocarb & 208 & $\mathrm{C}_{11} \mathrm{H}_{16} \mathrm{~N}_{2} \mathrm{O}_{2}$ & 0.14 \\
\hline 25 & 46.82 & Tetracosanol & 355 & $\mathrm{C}_{24} \mathrm{H}_{50} \mathrm{O}$ & 0.91 \\
\hline 26 & 47.17 & Cholesterol & 387 & $\mathrm{C}_{27} \mathrm{H}_{46} \mathrm{O}$ & 0.19 \\
\hline 27 & 47.39 & Methyl-6-formyl-3-pyridinecarboxylate & 165 & $\mathrm{C}_{8} \mathrm{H}_{7} \mathrm{NO}_{3}$ & 2.73 \\
\hline 28 & 47.49 & 9-(Methylaminomethyl)anthracene & 221 & $\mathrm{C}_{16} \mathrm{H}_{15} \mathrm{~N}$ & 1.67 \\
\hline 29 & 50.15 & 1-Heptacosanol & 397 & $\mathrm{C}_{27} \mathrm{H}_{56} \mathrm{O}$ & 0.48 \\
\hline 30 & 50.60 & $\beta$-Sitosterol acetate & 457 & $\mathrm{C}_{31} \mathrm{H}_{52} \mathrm{O}_{2}$ & 15.49 \\
\hline 31 & 50.94 & 5-Bromo-2-fluorocinnamic acid & 245 & $\mathrm{BrC}_{6} \mathrm{H}_{3}(\mathrm{~F}) \mathrm{CH}=\mathrm{CHCO}_{2} \mathrm{H}$ & 1.69 \\
\hline 32 & 52.24 & Pyridate & 379 & $\mathrm{C}_{19} \mathrm{H}_{23} \mathrm{ClN}_{2} \mathrm{O}_{2} \mathrm{~S}$ & 0.17 \\
\hline 33 & 53.15 & 2-Amine-6-methoxy purin & 165 & $\mathrm{C}_{6} \mathrm{H}_{7} \mathrm{~N}_{5} \mathrm{O}$ & 0.12 \\
\hline 34 & 53.57 & Benalaxyl & 325 & $\mathrm{C}_{20} \mathrm{H}_{23} \mathrm{NO}_{3}$ & 0.11 \\
\hline 35 & 54.72 & $\beta$-humulene & 204 & $\mathrm{C}_{15} \mathrm{H}_{24}$ & 0.66 \\
\hline
\end{tabular}

TABLE-2

PHYTOCOMPONENTS IDENTIFIED IN THE DECOLORIZATION PETROLEUM ETHER EXTRACT OF THE LEAVES OF Mussaenda esquirolli Lévl.

\begin{tabular}{cccccc}
\hline No. & RT $(\mathrm{min})$ & Phytoconstituents & m.w. & m.f. & Peak Area (\%) \\
\hline 1 & 2.73 & 2,5-Dimethyl hexane & 114 & $\mathrm{C}_{8} \mathrm{H}_{18}$ & 3.65 \\
2 & 2.90 & trans-1,3-Dimethyl cyclohexane & 112 & $\mathrm{C}_{8} \mathrm{H}_{16}$ & 4.09 \\
3 & 31.97 & Phytol & 297 & $\mathrm{C}_{20} \mathrm{H}_{40} \mathrm{O}$ & 42.86 \\
4 & 43.23 & Squalene & 411 & $\mathrm{C}_{30} \mathrm{H}_{50}$ & 47.15 \\
\hline
\end{tabular}

in liver and promote fatty acid $\beta$-oxidation. Therefore, phytol has some effects on the treatment of obesity and lipid me-tabolism disorders induced by insulin sensitivity ${ }^{12,13}$.

Squalene: Unique medicinal value of squalene has been in the extensive and indepth attention. Squalene can ameliorate immune system and improve the body's stress ability and immunity as an antioxidant ${ }^{14}$. In marine fish oil products, squalene is only identified to control tumors and widely used for medicine in cancer patients.

Many species of plants contain squalene, but the content is not high. Only in a few species, there are higher content of squalene. The experimental materials, Mussaenda esquirolli Lévl. can be considered as resource plant to extract squalene.

$\boldsymbol{\beta}$-Sitosterol acetate: Recently, lowering the cholesterol level through dieting such as functional foods has been attracted great attention. If the phytosterol or phytostanol are sufficient in the daily diet, the gastrointestinal assimilation of cholesterol can effectively reduce and thus it can lower serum cholesterol concentration ${ }^{15}$. $\beta$-sitosterol acetate belongs to the plant sterols and it has some functions beneficial to health such as lowering blood lipid and cholesterol ${ }^{16}$, antioxidant activity $^{17}$ and antitumor effects ${ }^{18}$. Therefore, Mussaenda 
esquirolli Lévl. can be considered as resources to develop commercial food ingredients and health food or beverage based on plant sterols to lower cholesterol.

\section{Conclusion}

In the present study, many phytoconstituents, belonging to essential fatty acids esters, alcohols, ethers, etc., have been identified from petroleum ether extract of the leaves of Mussaenda esquirolli Lévl. by GC-MS analysis. It could be concluded that Mussaenda esquirolli Lévl. contains various bioactive compounds. Linolenic acid, phytol, squalene and $\beta$-sitosterol acetate which were present in Mussaenda esquirolli Lévl. may be responsible for the medicinal and health care activity. Consequently, Mussaenda esquirolli Lévl. is recommended as important plant resources with great phytopharmaceutical and health function. Isolation and bioactivity study of individual phytochemical constituents will be presented in the further work.

\section{ACKNOWLEDGEMENTS}

This work was supported by the Science Foundation of Anhui Qingliang Mountain National Nature Reserve administration (Investigation of Biodiversity in Anhui Qingliang Mountain National Nature Reserve).

\section{REFERENCES}

1. G.D. Alejandro, S.G. Razafimandimbison and S. Liede-Schumann, Am. J. Bot., 92, 544 (2005).

2. H.-H. Hsue and H. Wu, Flora Reipublicae Popularis Sinicae Tomus 71(1); Science Press. Beijing, pp. $283-306$ (1999).

3. X.-F. Deng and D.-X. Zhang, J. System. Evolut., 46, 220 (2008).

4. X.-F. Deng and D.-X. Zhang, Acta Phytotaxon. Sin., 44, 608 (2006).

5. G.-T. Peng, S.-Z. Huang, H.-G. Li and J.-R. Fu, Plant Physiol. Commun., 37, 230 (2001).

6. S. Gopalakrishnan and E. Vadivel, Int. J. Pharm. Biosci., 2, 313 (2011).

7. D.-L. Wen and Y.-C. Zhou, Yunnan Agric. Sci. Technol., 6, 8 (2005).

8. S. Sridharan, M. Vaidyanathan, K. Venkatesh and A.A.J. Nayagam, $J$. Pharm. Res., 4, 741 (2011).

9. B.A. Watkins, Nutr. Res., 24, 3 (2004).

10. T. Arnhold, M.A. Mohamed Elmazar and Heinz Nau, Toxicol. Sci., 66, 274 (2002).

11. M. Heim, J. Johnson, F. Boess, I. Bendik, P. Weber, W. Hunziker and B. Flühmann, FASEB, 16, 718 (2002).

12. J. Gloerich, N. van Vlies, G.A. Jansen, S. Denis, J.P.N. Ruiter, M.A. van Werkhoven, M. Duran, F.M. Vaz, R.J.A. Wanders and S. Ferdinandusse, J. Lipid Res., 46, 716 (2005).

13. J. Gloerich, D.M. van den Brink, J.P.N. Ruiter, N. van Vlies, F.M. Vaz, R.J.A. Wanders and S. Ferdinandusse, J. Lipid Res., 48, 77 (2007).

14. G.S. Kelly, Altern. Med. Rev., 4, 29 (1999).

15. I. Wester, Eur. J. Lipid Sci. Technol., 102, 37 (2000).

16. S.N. Blair, D.M. Capuzzi, S.O. Gottlieb, T. Nguyen, J.M. Morgan and N.B. Cater, Am. J. Cardiol., 86, 46 (2000).

17. J. Plat, E.N.M. Onselen, M.M.A van Heugten and R.P. Mensink, Eur. J. Clin. Nutr., 54, 671 (2000).

18. M.-B. Chen and Q. Huang, J. Cereals Oils, 16 (2005). 